\title{
The silencing of Kierkegaard in Habermas' critique of genetic enhancement
}

\author{
Karin Christiansen
}

Published online: 21 February 2009

(C) Springer Science+Business Media B.V. 2009

\begin{abstract}
The main purpose of this paper is to draw attention to an important part of Habermas' critique of genetic enhancement, which has been largely ignored in the discussion; namely his use of Kierkegaard's reflections on the existential conditions for becoming one-self from Either/or and the Sickness unto Death. It will be argued that, although Habermas presents some valuable and highly significant perspectives on the effect of genetic enhancement on the individual's self-understanding and ability to experience him- or herself as a free and equal individual, he does not succeed in working out a consistent argument. The claim is that he fails to explain how the existential analysis is related to his reflections on the sociological and psychological impacts of genetic enhancement in the realm of communicative action. It is this lack of theoretical clarity, which seems to render Habermas vulnerable to some of the critique which has been raised against his theory from a number of different scientific disciplines and areas of research. Hence, the first part of the paper provides some examples of the nature and variety of this critique, the second part presents Habermas' own critique of genetic enhancement in the context of a dispute between so-called 'liberal' and 'conservative' arguments, and finally, the third part discusses the limits and possibilities of his position in a future debate about genetic enhancement.
\end{abstract}

Keywords Habermas - Liberal eugenics - Contingency · Genetic enhancement $\cdot$ Kierkegaard

K. Christiansen ( $\square)$

Centre for Health, Humanity and Culture, Department of Philosophy, University of Aarhus, Building 1465, Room 428, Jens Chr. Skous vej 7, 8000 Aarhus C, Denmark

e-mail: filkc@hum.au.dk

\section{Introduction}

Since the German philosopher and sociologist Jürgen Habermas published his lectures on the ethical implications of new genetic interventions such as Pre-implantation genetic diagnosis [PGD] and genetic enhancement in his book The Future of Human Nature (Habermas 2001, 2003), his viewpoint has been thoroughly discussed and critiqued by numerous philosophers, bioethicists, sociologists, anthropologists and by various researchers within the natural sciences (regarding this debate, see Edgar 2009). Philosophers and critical thinkers have not only pointed out internal inconsistencies within Habermas' argumentation: at least one philosopher has accused him of retreating from the anthropological perspective of his earlier work, and setting "forth a thin neo-Kantian based ethics of abstention that swallows and regurgitates the media-hyped jargon of genetic programming holus-bolus.” (Moss 2007, p. 139) Furthermore, sociologists, anthropologists and people working within the area of health (such as clinical geneticists and genetic counsellors) have emphasized Habermas' lack of insight into the realities of modern biomedicine and the numerous possibilities and hopes these new biomedical technologies hold for the creation of new forms of positive self-development and responsible self-government.

\section{Nicholas Rose's critique}

In his recent book The Politics of Life (Rose 2007) Nicholas Rose thus argues that Habermas' critique of future biotechnology does not seriously take into consideration the actual insights provided by sociological and anthropological studies into the way in which new reproductive technologies are in fact used, experienced and understood 
by the single individual and their families and relatives. Habermas is accused of not only presenting but also reproducing a series of negative expectations and conceptions about the possible implications of our interactions with present and future biotechnologies for the development of individual autonomy and self-responsibility. As Rose points out, Habermas only reluctantly agrees to the use of therapeutic interventions in case of severe genetic illness, while he rejects the use of genetic enhancement altogether. What counts as severe illness in Habermas' interpretation depends to some degree on our value-judgments and thus has to be continuously renegotiated by the members of society. The definition of disease is, however, not relativized as such. Habermas agrees with Buchanan et al.'s definition of disease and impairment—both physical and mental - as an "adverse departure from or impairments of species-typical normal functional organization" and that "the line between disease and impairment and normal functioning is thus drawn in the relatively objective and non-speculative context provided by the biomedical sciences, broadly construed." (Buchanan et al. 2000; Habermas 2003, p. 123)

In Rose's view, Habermas' scepticism toward genetic interventions is a sign of his profound blindness to the ways in which the modern somatic-oriented risk-conscious individual can gain access to new forms of identification and incorporate new strategies for responsible action (selfgovernment) through the use of these new technologies in situations where, for example, a risk of genetic predisposition is becoming known. We already see numerous examples of the creation of new forms of identification and integration of productive self-management and self-development strategies in the dynamic relationship between the pre-disposed individual and the modern medical technologies and between the various actors in rapidly growing networks of patients and/or relatives.

In his critique of Habermas' reflections on the moral implications of genetic enhancement, Rose argues that Habermas is presenting us with a mistaken or exaggerated notion of the abilities of future biotechnology to provide us with methods and knowledge enabling the genetic enhancement of various emotional, physical or cognitive capacities (such as enhanced memory). The idea that the use of these new technologies should open the gates to a post human future, he describes as 'overblown'-including the worries which go with this kind of thinking (Rose 2007, p. 253). Yet, Rose acknowledges that Habermas' way of describing the problems following on from the use of technologies of genetic enhancement is valid and sociologically interesting in a certain respect: it provides us with an important perspective on 'an emergent form of life'. He thus values Habermas' particular perspective on par with other theoretical or non-theoretical expressions and elaborations on identity and possible scenarios for selfdevelopment in the future. Habermas' visions of an emergent form of life are thus considered by Rose as important for our present discussions about what we do and what we should do in the future, though not regarded as imperative or self-evident in the general discussion about new biotechnologies as such. However, the perspective presented by Habermas is not just expressing a certain vision about the future-it is also contributing to the production of future forms of identification due to its inherent power to describe and interpret relevant relationships and interactions between the individual and new kinds of technology. In the poststructuralist context of Rose' work, Habermas' argumentation is thus contemplated in its 'surface' structure, as are all other perspectives on the interactions between actor and technology.

\section{The debate between 'liberal' and 'conservative' thinkers}

'Liberal' thinkers on genetic enhancement such as Nicholas Agar and John Harris tend to see a number of common viewpoints reflected in the works of Habermas, Leon Kass, Francis Fukuyama (Fukuyama 2002) and Michael Sandel (Sandel 2007). Agar and Harris consider this a group of 'conservative' thinkers, all displaying a sceptical and hesitant attitude towards the use of new reproductive technologies such as PGD and other predictive methods, and warning against the potentially harmful ethical, political and socio-economic consequences of developing and using new technologies of genetic enhancement. They all worry that the use of techniques of genetic enhancement will have the power to fundamentally alter or perhaps disrupt our human nature and our human self-understanding.

Nicholas Agar and John Harris, among others, reject their 'bleak' conception of our future interaction between technology and human nature, and point out the futility of maintaining any absolute distinction between the natural and the artificial. These distinctions, they claim, are based on essentialist and to some extent metaphysical ideas about the human constitution, which can no longer be maintained. Moreover, they argue that these conservative thinkers are making determinist assumptions about the interactions between the gene and human development, which do not correspond with the findings of natural science. Within this deterministic framework far too much weight is placed on the ability of the gene to express itself, quite independently of the impact of the environmental context or the active participation of the individual subject.

According to Agar's interactionist view (Agar 2004) on the relationship between genes and human development, a genetic intervention, such as the enhancement of particular 
athletic skills, will only have a chance of coming into being as intended, if the subject collaborates with the necessary dietary, educational, physical and motivational requirements. Within this interactionist framework there seems to be scope for the subject to choose to collaborate or refuse to collaborate with the intended intervention. In other words, the subject is not necessarily being determined by the genetic enhancement intervention and the idea that a particular genetic enhancement should be irreversible or impossible to 'talk to' and perhaps even oppose as an adolescent (as Habermas suggests) is discarded as mere speculation.

Some of the horror visions of enhanced individuals being somehow 'trapped' and suppressed in a designed body and a particular style of life set apart from other human (natural) forms of life, are found in numerous versions of popular science and science-fiction. A number of liberal thinkers contend that these visions are reproduced by the conservative thinkers in their critique of genetic enhancement, where they serve the purpose of scaring people off from developing or using these new technologies. Moreover, they argue that the conservative discourse on genetic enhancement is marked by anxiety that these new interventions will be able to challenge or destroy a particular image of ourselves as finite and vulnerable beings, who are placing high value on exhibiting adequate restraint in matters of human enhancement due to our limited ability to foresee the consequences of our scientific and technical interventions in the being of the other.

In his book, Enhancing Evolution (Harris 2007) the philosopher John Harris mocks this way of thinking and discards it as a celebration of the status quo. In Harris' thinking, the viewpoint of Leon Kass for example-and in particular Kass' celebration of human dignity and human finitude-expresses a rigid, narrow and puritan conception of human life. Kass seems to embrace our ability to acknowledge the tragedy of human death and suffering as a productive and necessary condition for the good human life, and he therefore regards the various means to postpone death or expand our life-span through genetic enhancement as a manifestation of hubris, or a kind of illegitimate human acquisition of divine powers over life and death. Writing in a derogatory tone seldom found in serious academic writing, Harris vents his frustration against Kass' defense of human conditions and values in a critique which is also unmistakenly ad hominem. He writes,

"I do not recognize finitude, only the limitless possibilities of the human spirit and of human ingenuity. If Kass wishes to remain a limited human being, that is of course a matter for him. The sinister message is in the tail of Kass's agenda; he wishes to "treasure and defend"." Treasuring is fine-Kass himself is something of an international treasure-but when he seeks to defend limitations he trespasses on the freedom of others and seeks to shackle the human spirit within the confines of the limits of his own desires and imagination. This is something those who defend freedom will wish to oppose." (137)

In Harris' perspective, the negative consequences of 'treasuring and defending' Kass' values and conceptions of the good human life would be that parents would be deprived of their freedom of choice in matters of human reproduction. Parents would have to submit to external values and norms, which they might find it hard to acknowledge and respect as their own. In other words, submitting to foreign values and ideals would undermine their autonomy in reproductive matters, including their choice of human enhancement. Moreover, it would limit the possibilities of both parent and child to expand their options and form their lives independently. The implication is that any trust in parents' own ability to use their imagination and empathy for the sake of the good of their particular child, would be suppressed by this paternalistic regime.

In some of his writings Kass attributes great importance to the role of our great literary narratives in mediating and conveying profound wisdom about the human and what constitutes natural human boundaries (Kass 2002, 2003, 2004). The (pre-theoretical) moral insights we gain from our engagements with great narratives often reveal themselves spontaneously as feelings of revulsion or shame when we experience something in our daily life which provokes or disturbs our sense of human dignity or humanness. Feelings of revulsion or disgust (often described as the 'Yuck'-reaction) are some of the morally signifying emotional responses overwhelming an individual who is confronted with biotechnological possibilities which oppose, provoke or render superfluous important human values. Kass mentions as important human values the erotic dimension of human reproduction (which could be rendered superfluous by the use of new technologies of PID or genetic enhancement) or the dignity of life (coming under attack if the parents began to shape the most vulnerable being (the embryo) in an image of their own choosing).

There is no doubt that Harris considers this way of arguing against the new techniques of enhancement to be deeply irrational, unsubstantiated and narrow-minded. This way of thinking goes directly against the liberal idea of leaving it up to the parents to choose to optimize the potential of the child in a way that would enable the child to shape and control its own world in the best possible way. Harris goes as far as to suggest that all responsible parents will choose to enhance their children in the future and thus 
be pro-active in shaping evolution in a way they find more desirable and adequate in light of the changing ecosystem. By taking the means to control the direction of the human evolution, human beings will no longer have to submit to the 'natural lottery of life'; they will be able to develop into a better species-perhaps a new species-who will be better equipped to survive and prosper under different societal, technological and environmental circumstances (Harris 2007, p. 4). Whether Harris is himself an essentialist in his view on human evolution will not be debated in this context.

A frequent and significant question asked by the critics of genetic enhancement is, of course, whether the freedom claimed by the proponents of a liberal eugenics could turn out to be detrimental to the enhanced being's own sense of autonomy and experience of freedom to act and choose independently. Is it possible, for example, that Harris' critique of Kass' subjective, narrow, unimaginative way of thinking could be directed against Harris himself in his emphasis on the rights of the parents to use their own imagination in the choice of genetic enhancement? Could it be that the enhanced being would not appreciate but rather oppose the choice of genetic enhancement, pointing out the parent's lack of reflection on their own finitude, their own historically conditioned consciousness, in applying their judgment and (limited) imagination on something which would have appeared in the abstract to them? Would these reflections on the intricate relationship between the conditions of human self-understanding and the enhanced being's experience of freedom and autonomy have to be discarded as outdated 'thanatos' thinking (qua the neoNietzschean approach defended by Harris), subduing the values of human power, creativity and freedom of choice for the sake of 'treasuring and defending' old traditions? Where does Habermas stand in this debate about the relationship between freedom, human self-understanding and genetic enhancement?

\section{Habermas on the relationship between normative self-understanding, freedom and human contingency}

In The Future of Human Nature Habermas presents a surprising and somewhat controversial claim, that the condition of our normative self-understanding and the development of self-consciousness and a personal sense of freedom is intimately linked to the acknowledgement of "the contingent process of human fertilization, which results from what is now an unforeseeable combination of two different sets of chromosomes" (Habermas 2003, p. 13). These thoughts were completely absent from his line of thinking in, for example, A Theory of Communicative Action published in 1988 (Habermas 1988 (German
Edition)). In this work Habermas presented the view that human self-understanding and the development of selfconsciousness come into being in the process of socialization, through the engagement with work, in the auseindersetzung with a plurality of cultural values, and not least, in-and-through the medium of rational discourse.

In his "Discourse ethics: Notes to a Program of Philosophical Justification" Habermas explained, "I call interactions communicative when the participants coordinate their plans of action consensually, with the agreement reached at any point being evaluated in terms of the intersubjective recognition of validity claims" and he continues, "Whereas in strategic action one actor seeks to influence the behaviour of another by means of the threat of sanctions or the prospect of gratification in order to cause the interaction to continue as the first actor desires, in communicative action one actor seeks rationally to motivate another by relying on the illocutionary binding/bonding effect (Bildungseffect) of the offer contained in the speech act" (Habermas 1990, p. 58). Hence, whereas in the strategic action the person presenting his arguments might have ulterior motives and hence play a role hiding his true intentions, in communicative action one is willing to submit to what Mead called a principle of "ideal role taking", making possible the recognition of the argument by all concerned (65). This principle of "ideal role taking" is meant to be compelled by what Habermas terms the principle of universalization. As Habermas explicates, every valid norm has to fulfil the following condition: "(U) All affected can accept the consequences and the side effects its general observance can be anticipated to have for the satisfaction of everyone's interests (and these consequences are preferred to those of known alternative possibilities for regulation)" (65). Habermas explicitly writes that practical discourse is not a procedure for generating justified norms but a "procedure for testing the validity of norms that are being proposed and hypothetically considered for adoption. That means that practical discourses depend on content brought to them from outside." (103)

In Habermas' view it does not make any sense to say that one can in fact choose between communicative and strategic action. That option exists only abstractly for someone who takes the contingent perspective of an individual actor. Belonging to a life-world in which symbolic structures are constantly reproduced through cultural tradition, social integration and socialization implies that one does not actually have a choice of standing back from the communicative medium of action oriented toward reaching an understanding. As Habermas writes:

"There is no other, equivalent medium in which these functions can be fulfilled. Individuals acquire and sustain their identity by appropriating tradition, 
belonging to social groups, and taking part in socializing interactions. That is why they, as individuals, have a choice between communicative and strategic action only in the abstract sense, i.e., in individual cases. They do not have the option of longterm absence from contexts of action oriented toward reaching an understanding. That would mean regressing to the monadic isolation of strategic action, or schizophrenia and suicide. In the long run such absence is self-destructive." (102)

If we return to Habermas' critique of a liberal eugenics in The Future of Human Nature and have these considerations about the relationship between communicative action and identity in mind, we will be able to gain a better understanding of why Habermas is alarmed by the prospects of genetic enhancement. According to Habermas, something essential is happening to the individual's ability to participate as an equal in the communicative medium of action, if parents begin to introduce genetic enhancement into the being of their (prospective) child. The enhanced might find it hard to identify with his own arguments and perceive of them as his own (claiming authenticity), when he is made aware that his parents have acted strategically by interfering with the natural part of his condition. The enhanced might possibly (but not necessarily) get the sense that the intervening parents have built their own preferences into his genome "as a fifth column" and thus acted as intrusive co-authors to his life.

It is important for Habermas to stress what happens when we begin to consider interfering with the natural part of our human condition, namely, that something which was previously hidden from our consciousness and thus remained unthematized reveals itself as essential. When we consider the value of this natural condition (the contingency of the human fertilization) more closely it turns out to be "a necessary presupposition for being-able-to-beoneself and for the fundamentally egalitarian nature of our interpersonal relationships" (Habermas 2003: 13). If this natural condition is not being respected as absolutely fundamental to the beings that we are, this might consequently undermine the possibility of "ideal-role taking", which serves as a regulatory tool for processes of mutual recognition leading to understanding. It might hinder the development of a democratic society of citizens capable of recognizing themselves and each other as equals in communicative action. Furthermore it might threaten the very possibility of sustaining the framework for communicative action, which Habermas has developed and maintained throughout the years.

In this context, it is surprising to see that almost none of the articles commenting on and critiquing Habermas' point of view have shown any interest in his application of
Soeren Kierkegaard's philosophical thinking. These are considerations about the conditions of being and becoming one-self, which Habermas could have used more explicitly to substantiate his critique of genetic enhancement. On the other hand, there might also be problems in applying Kierkegaard's Existenz-philosophical perspective as a formal approach in a substantive debate about genetic enhancement. Does it make any sense to claim that the techniques of genetic enhancement can influence and perhaps undermine the development of individual identity and selfunderstanding on an existential level? What are we left with, if we discard that hypothesis? Some weak assumptions about the possible psychological consequences of genetic enhancement, which could have gained considerably in substance if the author had drawn on insights from contemporary empirical research into the cognitive and emotional impact of modern technological, environmental or educational types of intervention on the development of child- and mature identity (as Rose might suggest)? In order to discuss these questions, however, we first need to inquire more deeply into Habermas' philosophical 'Sitz im Leben'.

\section{A postmetaphysical answer to the question about the 'Good life'?}

Some people might wonder why Habermas introduces his critique of the prospects of a liberal eugenics with the question as to whether there are "postmetaphysical answers to the question: What is the "Good Life" "? The question is, however, a pressing and important one, considering the fact that modern philosophy no longer pretends to be speaking from a superior and secure vantage point from which it can give authoritative or univocal answers to questions concerning the individual or collective conduct of life (Habermas 2003, p. 1). Previously the disclosure of authoritative, exemplary and right ways of living was embedded in an absolute conception relating man's ways of choosing and navigating in the world to the order of cosmos, nature and history. This has now been substituted by a philosophical reflection, which takes as a basic premise for any discussion of the good human life that we are embedded in a plurality of worldviews, cultures and individualisation of lifestyles.

Habermas is drawing attention to the attempt of Rawls' Political Liberalism to formulate a theory about the conditions for a just society, which responds to the plurality of worldviews and individualism of lifestyles and seeks to guarantee every citizen "an equal freedom to develop an ethical self-understanding, so as to realize a personal conception of the "good life" according to one's ability and choices" (2). When considering questions of justice, 
practical philosophy seeks to "clarify the moral point of view from which we judge norms and actions whenever we must determine what lies in the equal interest of everyone and what is equally good for all" (3).

On the surface it looks as if moral theory and ethics are still engaging with the question about the right conduct for me and for us. However, there has been a major shift in perspective and emphasis. Today, we can no longer assume that we speak from a shared understanding of common duties and rights, which everybody has agreed to submit to. Habermas emphasizes that the "ought" has a different sense when applied solely to my own existence, and to the choices I make in various times and circumstances in the interests of my own life, the life of my family, or the community I am situated in. The moral question only makes sense in the context of a particular life history or a unique form of life and is intimately connected to questions about identity. In other words, philosophy cannot formulate any answers to questions about who we are or want to be by abstracting itself from the particular context and the particular actors involved; if it did, it would be accused of being inherently dogmatic or paternalistic.

What is thus the task and domain of philosophy, when the grand narratives of metaphysics and religion can no longer provide philosophy with authoritative claims and criteria for judgments of truth, and when philosophy is forced to stand back from any intervention in "this struggle of gods and demons"? (4). Habermas explains that when we are considering important ethical and moral questions "philosophy retires to a metalevel and investigates only the formal properties of processes of self-understanding, without taking a position on the contents themselves" and as he points out, "that may be unsatisfying, but who can object to such a well-justified reluctance" (4). Thus, when Habermas argues that philosophy must limit itself to the investigation of the formal properties of the processes of self-understanding, this obviously does not imply that he is blind towards the pluralism of life-forms and various forms of development of identity (as Rose seems to suggest). One can agree or disagree with Habermas' methodical "depoliticalization" of his philosophical project, but one can hardly accuse him of not providing us with reasons why he-precisely in view of a pluralism of worldviews-is choosing a formal account.

As we will see in the following, Habermas is drawing heavily on Kierkegaard's ethical reflections in Either/Or (Kierkegaard 1980a) in his attempt to work out a solid philosophical foundation for his critique of a liberal eugenics. He emphasizes that Kierkegaard's post-metaphysical ethics provides us with answers to questions about the not-unsuccessful life, which are "sufficiently formal, that is, in view of a legitimate pluralism of worldviews that prohibits any form of paternalism in the area of genuinely ethical advice" (6). This implies that Kierkegaard's general statements about the modes of "being-able-to-be-oneself" are not thick descriptions, although they still have normative content. Habermas writes, "Because this ethics judges the existential mode, but not the specific orientation of individual life-projects and particular forms of life, it satisfies the conditions of a pluralism of world-views" (11).

Habermas introduces his philosophical discussion about genetic enhancement by making it clear that the whole idea of postmetaphysical abstention is challenged when we are faced with questions of "species ethics". He emphasizes that philosophy can be forced to take a substantive position "as soon as the ethical self-understanding of languageusing agents is at stake in its entirety" (11). We are currently confronted with new biotechnological and bioscientific advances presenting us with new types of therapeutic interventions, which might later be developed for enhancement purposes. These new biotechnological advances are thus forcing us to discuss the right understanding of our cultural forms of life, which might help us to "control any normative judgment of ongoing judgment" before we slip down the slope of unregulated, short-sighted, subjective and market-driven enhancement. In Habermas' view we cannot leave this important question to be decided by natural scientists or people interested in superior artificial intelligence, who are often inherently reductionist in their conception of 'the human'.

\section{Kierkegaard's postmetaphysical ethics}

Habermas begins The Future of Human Nature by situating his own philosophical standpoint between a Kantian theory of justice and a Kierkegaardian ethics of subjectivity. These thinkers provide the theoretical background for his defence of "the restraint that postmetaphysical thinking exercises regarding binding positions on substantive questions of the good or the un-misspent life" (vii). In the next section we are going to look more closely at Habermas' description of some of Kierkegaard's reflections on the conditions for self-understanding, which he later seeks to apply in his critique of a liberal eugenics. As mentioned above, Habermas is drawing on Kierkegaard's analysis of the relationship between the ethical and aesthetic stage of existence in Either/Or and the various modes of existence described in Sickness unto Death (Kierkegaard 1980b), in order to draw out a so-called formal approach to the question about enhancement.

As Habermas explains, Kierkegaard's description of the aesthetic mode of being towards life, where the single individual is acting towards the other in a playful, experimenting manner with no other purpose than enjoying the fleeting moment and letting her- or himself be carried away 
by the pleasures of life (while acknowledging the relativity of values, interests or beauty) is contrasted in Either/Or with the ethically resolute conduct of life. The ethical being is 'making himself at home' and creates continuity in his own life by choosing to engage and making binding commitments to particular human beings and tasks in his life. In the moment of choice, in which he relates passionately to the demands and requirements of the present situation, he is both distancing himself from his egotistical, hedonistic concerns, and is at the same time pulling himself out of a fragmented world, in which no meaning or value is given. $\mathrm{He}$ is choosing himself as an infinitely valuable being, while connecting to himself as an individual and free being having an infinite interest in the success of his own life-project. However, this does not imply that he has absolute power to narrate himself as he pleases. The individual might be characterized as being his own editor. As Kierkegaard writes in Either-Or, "he is also fully aware that he is responsible, responsible for himself personally.... Responsible to the order of things in which he lives, responsible to God."(Kierkegaard 1980a, p. 260, cited in Habermas 2003, p. 7).

In Sickness unto Death Kierkegaard describes the way in which despair is an inescapable condition of human existence. It reveals itself as anxiety in the existence of anyone who senses that the task of life is to become one-self, but who nevertheless shies away from making the necessary movements towards responsible (or authentic) self-acquisition. For the person who is slowly becoming aware of his true destiny, but who is not prepared or willing to escape his ego-centered consciousness, there are various modes of despairing. Kierkegaard mentions three alternatives: "in despair not to will to be oneself. Or even lower: in despair not to will to be a self. Or lowest of all: in despair to will to be someone else" (Kierkegaard 1980b, p. 111, cited in: Habermas 2003, p. 9).

There is, however, a way out of this existential despair in Kierkegaards philosophical approach. In order for healing to occur, the despairing individual first has to understand that his sense of despair is not conditioned by circumstances, but rather lies in his attempts to escape himself. The cure is thus bound up with a will to be oneself. However, it would be a mistake to think that the power to make this reversal can be found in the individual's own independent will to be himself. The limitations of the power of the human will must be acknowledged by the individual as well. As Habermas writes, "The hopeless failure of this last act of will-the stubborn wanting to be oneself entirely on the basis of one's own resourcespushes finite spirit to transcend itself and recognize its dependence on the Other as the ground of its own freedom" and he continues, "in relating itself to itself and in willing to be itself, the self rests transparently in the power that established it" (9). Only in the recognition of one's sinfulness and through the grace of God, can one establish the right relationship to oneself and be acting and choosing as a free being in relation to the other. When this relationship is established, the individual will not choose to project his projects and goals into some transcendental realm or bury himself in some nostalgic notion of past possibilities of life. He chooses himself passionately as a concrete and unique individual (hin enkelte) and acts as a normal citizen in the social sphere by reflecting critically on his failings in the past and by showing adequate remorse for whatever he failed to do or failed to be. Only in and through that movement can the determining forces of past failings and sinful acts be effectively neutralized. The movement of self-acquisition can therefore only have true emancipatory power if the individual succeeds in transcending himself as the sole centre of the universe and relates to the Absolute Other as the very condition for the hope of being able to be oneself.

Kierkegaard's answer to the question of the right way to live might be a post-metaphysical one, but as Habermas writes, it is also theological. Habermas is choosing him for his project because he gives answers which are "sufficiently formal" - and hence can be used in his own formal critique of liberal enhancement. However, as we have seen, Kierkegaard is very far from only providing us with formal answers, when he considers the 'conversion' from existential despair to a free existence in which one becomes oneself by recognizing one's dependence on the relationship to the Other as the ground for one's freedom. The question is, whether Habermas actually succeeds in applying Kierkegaard's analysis of the despairing modes of existence to his discussion of the problems relating to genetic enhancement. What happens to the existential question of choosing oneself passionately (which can only really happen in Kierkegaard's optics by relating to a transcendent power), when Habermas is exchanging God for the subject-transcending power of language? As Habermas points out, Kierkegaard was attacking Hegel's formalism and Hegel's subjugation of the individual in the process of the absolute spirit becoming itself. Habermas also explains that Kierkegaard is responding to the fact that Kant left us with no real answer to the question as to why we should act morally. He writes, "Kierkegaard is convinced that the ethical form of existence produced by one's own efforts can be established only in the relation of the believer to God. As long as we ground morality as the standard for self-scrutiny in human knowledge (as in the Socratic or Kantian approaches), the motivation for converting moral judgment into practice is lacking. Kierkegaard objects not so much to the cognitive meaning of morality as to its intellectualistic misunderstanding." (7) 
This is where Kierkegaard's emphasis on passion (lidenskab) comes in. However, what happens to this passionate existential self-encounter in Habermas' own account? Does he actually manage to 'translate' Kierkegaard's existential reflections into his own account of what happens to the enhanced being's possibility of becoming one-self, or does he fail to establish the link between the existential approach and his elaboration on the communicative and sociological framework in which the identityformation is taking place? In the following it will be argued that Habermas might be raising a number of important questions about the impact on genetic enhancement on the ability of the individual to experience himself as a free agent with an open future and with a sense of responsibility for his own life-but that he nevertheless fails to argue convincingly for the way in which the child is affected on the existential level. Because he does not succeed in explaining the relationship between the existential analysis and the mainly empirical, sociological and psychological observations he makes, he renders himself vulnerable to critique from researchers within a number of different disciplines.

\section{Habermas' critique of liberal eugenics}

In Habermas's view the phenomenology of Kierkegaard's Sickness unto Death is drawing attention to the important fact that "the finite spirit depends on enabling conditions beyond its control" (10). While we are no longer able to identify these enabling conditions as "God in time" under the premises of postmetaphysical thinking, we can all agree that we are depending on one another and the medium of language in our attempts to come to an understanding of ourselves as finite beings. As historical and social beings we are embedded in a linguistically structured lifeworld, which is presenting us with the possibilities of coming to an understanding. According to Habermas, we encounter a transcending power, when we are engaging with one another about a subject matter relating to the world or ourselves in the medium of language. It is not possible to describe precisely what is happening to us in this process of coming to an understanding. As Habermas writes, "No one possesses exclusive rights over the common medium of the communicative practices we must intersubjectively share. No single participant can control the structure, or even the course, of processes of reaching understanding and selfunderstanding" (10). It is the logos of language that "embodies the power of the intersubjective, which precedes and grounds the subjectivity of the speakers" (11). Even though we do not control or possess the language, it still remains 'our language' - it is the medium in-andthrough which we present and justify our claims to one another. Hence, what makes being-ourselves possible is no longer an absolute power but a trans-subjective power in Habermas' theory.

At the end of his brief description of the way in which language has now replaced the role of God as a "transcending power," Habermas makes the very important observation that "the unconditionedness of freedom is a necessary presupposition of our practices, but beyond the constituents of "our" form of life they lack any ontological guarantee" (11). This is where Habermas' concrete engagement in the debate about genetic enhancement begins, and where we connect with the aforementioned question about the premises for our cultural form of life. The question is, whether a change in our cultural life form will be taking place and impact on the very conditions for "the unconditionedness of freedom of truth," if we open the gates for genetic enhancement? We have already considered Habermas' central view that it is a necessary presupposition for being-able-to-be-oneself, and for the fundamental egalitarian nature of our interpersonal relationships, that we are not tampering with the contingency of the human fertilization-process. In our ordinary interactions we are not usually conscious of our condition as contingent beings. As Heidegger describes in his Daseinanalysis, (Heidegger 2002) we are normally situated in a world of things, beings and relationships, which we take for granted. It is only when something 'breaks' or starts behaving in a different way, that we are beginning to reflect on the constitution or the being of the subject matter (i.e. his Zeug-analysis). This is similar to the process taking place when we are confronted with the possibility that parents might be able to make 'positive' adjustments to the somatic bases of the child. We begin to reflect on what we consider as fundamental to our self-understanding and our ability to act spontaneously or authentically as equal partners in a dialogue. We begin to question whether it is possible that another person's one-sided and strategic action can affect the person intervened upon in such a way that he cannot actually choose himself as the author of his life-but is somehow barred from interacting as an equal in the realm of communicative action. Could it be that this person, who was told about the enhancement, would lack a "mental presupposition for assuming a status necessary for her, as a legal person, to enjoy equal civil rights"? (Habermas 2003, p. 78)

Habermas is describing a number of possible psychological and social effects of knowing about one's genetic enhancement. Besides speaking about a lacking mental presupposition, he mentions the impact on the adolescent's sense of worth and self-esteem. He continues these reflections when he speaks about the possible difficulty of overcoming the asymmetrical relationship between parent and child in the case of genetic enhancement. Whereas in 
the course of a normal socialization process the child can choose to argue against the views of the parents and oppose their ideas and views, there is no way to oppose or question the 'mute' intervention of genetic enhancement. The freedom of self-critical appropriation and hence the possibility of taking full responsibility for one's life story might not be the same if one is aware of the enhancement. In Habermas' view the decision to enhance is irreversible and would most likely affect one's sense of having an open future. As Habermas writes:

"This new type of relationship offends our moral sensibility because it constitutes a foreign body in the legally institutionalized relations of recognition in modern societies. When one person makes an irreversible decision that deeply intervenes in another's organic disposition, the fundamental symmetry of responsibility that exists among free and equal persons is restricted. We have a fundamentally different kind of freedom toward the fate produced through the contingencies of our socialization than we would have toward the prenatal production of our genome. The developing adolescent will one day be able to take responsibility for her own life history; she will be able to take responsibility for her own life history; she will be able to take possession of what she is. That is, she can relate to her process of development reflectively, work out a revisionary self-understanding, and in a probing manner retrospectively restore the balance to the asymmetrical responsibility that parents have for their children's upbringing. This possibility of a self-critical appropriation of one's own developmental history is not available in regard to genetically manipulated dispositions." (14)

Although Habermas is speaking about the determining effect of knowing about the genetic enhancement, it would be a mistake to consider him a genetic determinist. Habermas nowhere implies that a particular genetic enhancement would necessarily come into being as intended. He is specifically saying that the enhanced being does not necessarily have to experience any problems in authentic self-acquisition, if he agrees fully with the preferences of the parents and is happy to cooperate with their interventions. Nevertheless, he clearly maintains that the knowledge about being enhanced might be experienced as burdensome on a psychological level. Whether this psychological 'burden' of knowing about the intervention would have an impact on the existential level remains unclear. As stated above, the relationship between the psychological and sociological analysis and the existential analysis is not sufficiently brought out in Habermas' work. Moreover he is not giving us any direction, as to how these perspectives might intersect by referring, for example, to any of the modern psychological theories using an existentialist approach. At the end of Habermas' discussion one cannot help but wonder, why Kierkegaard's analysis in Either-Or or in The Sickness unto Death, was given such a prominent place in The Future of Human Nature.

\section{Conclusion}

What would happen, if one gave Kierkegaard a voice instead of accepting Habermas' (no doubt unintentional) silencing of it in the present discussion? Clearly, more work needs to be done to elaborate more fully on his critical potential in the debate of genetic enhancement. However, if one took a Kierkegaardian approach to the question as to whether the intervention in the somatic bases of the child would impact on the ability of the child to become one-self, some Kierkegaard-scholars would undoubtedly maintain that the individual, regardless of his or her biological, sociological or psychological constitution, would have the option of choosing to become oneself. As Habermas pointed out in his interpretation of Kierkegaard, it is a sign of despair, if the individual is trying to escape from the particular circumstances and the biographical situation of his or her life. One could turn this question back at Habermas, and ask whether the intervention in the somatic basis of the child is so significant, and so significantly different from any other powerful impact on life, that the enhanced being would be unable to reconcile himself with himself in the moment of choice?

This leads on to a question which has often been raised against Habermas' view, namely, whether the actual interventions on the genetic level can be said to be significantly different from other kinds of parental intervention? How would the parents' choice to teach the child to be bilingual from a very early age be any different from the choice of genetic enhancement? Why do we discriminate between kinds of enhancements, instead of, as David Wasserman suggests (Wasserman 2003), considering the ways in which all kinds of parental interventions such as exposure to particular diets, education, training, genetic interventions can be abusive and oppressive, if they are not considering the being of the Other as Another?

As long as Habermas does not explain the way in which the existential and the psychological and sociological theories are related, he renders himself vulnerable to such kinds of critique, which focus explicitly on empirical matters. There is great confusion about how to approach and judge his theory because of this lack of clarification. In addition, it is curious that Habermas does not consider how the choice to enhance one's prospective child might affect the intervening person. One would have to ask what happens to the parents' self-understanding, when they are 
acting as co-authors to the life of their prospective child, before a concrete human relation is established-a relationship, which has so far been fundamental to our decisions to partake in the development and cultivation (Bildung) of the child. If Habermas should choose to elaborate further on his existentialist approach to genetic enhancement, it would be helpful if he expanded his perspective to include an analysis of the intervening individual which would address important questions such as these.

\section{References}

Agar, N. 2004. Liberal eugenics-in defense of human enhancement. Oxford: Blackwell Publishing.

Buchanan, A., D. Brock, N. Daniels, and D. Wikler. 2000. From chance to choice-genetics \& justice. Cambridge: Cambridge University Press.

Edgar, A. 2009. The hermeneutic challenge of genetic engineering: Habermas and the transhumanists. Medicine, Health Care and Philosophy. doi:10.1007/s11019-009-9188-9.

Fukuyama, F. 2002. Our Posthuman Future-Consequences of the Biotechnology Revolution (trans: Rehg, W., Pensky, M., and Beister, H.) London: Profile Books.

Habermas, J. 1988. Theorie des Kommunikativen Handelns, Band 1-2. Frankfurt am Main: Suhrkamp.

Habermas, J. 1990. Discourse ethics: Notes on a program of philosophical justification. In Moral consciousness and communicative action. Cambridge: Polity Press.

Habermas, J. 2001. Die Zukunft der menschlichen Natur-Auf dem Weg zu einer liberalen Eugenik?. Frankfurt am Main: Suhrkamp Verlag.
Habermas, J. 2003. The future of human nature. Cambridge: Polity Press.

Harris, J. 2007. Enhancing evolution-the ethical case of making better people. New Jersey: Princeton University Press.

Heidegger, M. 2002. Being and time (trans: Macquarie, J. and Robinson, E.). New York: Harper San Fransisco.

Kass, L. 2002. Life, liberty and the defence of dignity — the challenge for bioethics. San Fransisco: Encounter Books.

Kass, L., et al. 2003. Beyond therapy, A Report of The President's Council on Bioethics, downloaded from: http://www.bioethics. gov/reports/beyondtherapy/index.html.

Kass, L. 2004. Being human: an introduction. In Being human-core readings in the humanities, ed. L. Kass.

Kierkegaard, S. 1980a. Either/Or, part 2 (ed. and trans: Hong, H.V., and Hong, E.H.). In Kierkegaard's writings, vol. 4. Princeton: Princeton University Press.

Kierkegaard, S. 1980b. The sickness unto death (ed. and trans: Hong, H.V., and Hong, E.H.) In Kierkegaards writings, vol. 19. Princeton: Princeton University Press.

Moss, L. 2007. Contra Habermas and towards a critical theory of human nature and the question of genetic enhancement. New Formations 60: 139-149.

Rose, N. 2007. The politics of life itself-biomedicine, power, and subjectivity in the twenty-first century. Princeton: Princeton University Press.

Sandel, J.M. 2007. The case against perfection-ethics in the age of genetic engineering. Cambridge: The Belknap Press of Harvard University Press.

Wasserman, D. 2003. My fair baby: What's wrong with parent's genetically enhancing their children? In Genetic prospectsessays on biotechnology, ethics and public policy, ed. V. Gehring, s.273-s.294. London: W.W. Norton \& Company. 